\title{
Modeling water and isoproturon dynamics in a heterogeneous soil profile under different urban waste compost applications
}

- Vilim Filipovića, b, c

- Yves Coquet ${ }^{\mathrm{b}}$,

- Valérie Pot $^{\mathrm{c}}$

- Sabine Houot ${ }^{\mathrm{c}}$

- Pierre Benoit ${ }^{\mathrm{c}}$

- $\quad$ a Department of Soil Amelioration, Faculty of Agriculture, University of Zagreb, Svetošimunska 25, 10000 Zagreb, Croatia

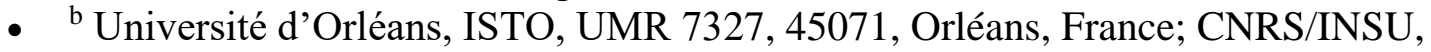
ISTO, UMR 7327, 45071 Orléans, France; BRGM, ISTO, UMR 7327, BP 36009, 45060 Orléans, France

- $\quad{ }^{\mathrm{c}}$ UMR ECOSYS, INRA, AgroParisTech, Université Paris-Saclay, 78850 ThivervalGrignon, France

\section{Highlights}

-Water and isoproturon losses at 45-cm depth were monitored for 6 years.

- Compost addition to soil reduced water and isoproturon losses.

-Isoproturon losses occur due to preferential flow events shortly after application.

-HYDRUS-2D described water flow accurately in all three plots.

-Model reproduced isoproturon dynamics except large preferential flow events.

\section{Abstract}

Compost amendments and tillage practices can modify soil structure and create heterogeneities at the local scale. Tillage affects soil physical properties and consequently water and solute transport in soil, while compost addition to soil influences pesticide sorption and degradation processes. Based on the long-term field experiment QualiAgro (a INRAVeolia partnership), a modeling study was carried out using HYDRUS-2D to evaluate how two different compost types combined with the presence of heterogeneities due to tillage affect water and isoproturon dynamics in soil compared to a control plot. A municipal solid waste compost (MSW) and a co-compost of sewage sludge and green wastes (SGW) have been applied to experimental plots. In each plot, wick lysimeters, TDR probes, and tensiometers were installed to monitor water and solute dynamics. In the plowed layer, four zones differing in their structure were identified: compacted clods, non-compacted soil, interfurrows, and the plow pan. From 2004 to 2010, the unamended control (CONT) plot had the largest cumulative water outflow $(1388 \mathrm{~mm}$ ) compared to the MSW plot $(962 \mathrm{~mm})$ and SGW plot $(979 \mathrm{~mm})$. After calibration, the model was able to describe cumulative water outflow for the whole 2004-2010 period with a model efficiency value of 0.99 for all three plots. The CONT plot had the largest isoproturon cumulated leaching $(21.31 \mu \mathrm{g})$ while similar cumulated isoproturon leaching was measured in the SGW $(0.663 \mu \mathrm{g})$ and MSW $(0.245 \mu \mathrm{g})$ 
plots. The model was able to simulate isoproturon leaching patterns except for the large preferential flow events that were observed in the MSW and CONT plots. The timing of these preferential flow events could be reproduced by the model but not their magnitude. Modeling results indicate that spatial and temporal variations in pesticide degradation rate due to tillage and compost application play a major role in the dynamics of isoproturon leaching. Both types of compost were found to reduce isoproturon leaching on the 6 year duration of the experiment.

Keywords : Soil heterogeneity; Compost amendments; Conventional tillage; Water flow; Isoproturon; HYDRUS-2D

\section{Introduction}

Compost application to soils is getting more importance due to its benefits in improving crop productivity and soil quality. It has been accepted as an ecological method for the disposal of organic wastes, while maintaining or increasing soil fertility at the same time (Diacono and Montemurro, 2010). Many types of compost made from municipal solid waste, sewage sludge or farmyard manure are applied nowadays to agricultural soils. These various compost ingredients can be mixed together in different amounts and may generate different impacts on agroecosystems. Compost addition to soil tends to affect soil physical properties by increasing soil aggregate stability (Annabi et al., 2011), plant available water and soil porosity (Curtis and Claassen, 2005), and by decreasing bulk density in the same time (Wong et al., 1999). In European conventional agriculture, compost is incorporated to soil by moldboard plowing. In addition to compost application, tillage can also affect soil hydraulic properties (Strudley et al., 2008 and Alletto et al., 2010). Schneider et al. (2009) found that tillage had greater influence on soil saturated hydraulic conductivity than urban waste compost addition. Combining compost addition with moldboard plowing can create compacted soil zones next to non-compacted soil zones containing large amounts of organic material. Large differences in soil hydraulic properties can be expected between these different soil zones, which can have significant effects on water and solute distribution within as well as beneath the tilled layer (Coquet et al., 2005a).

In addition to their effects on soil hydraulic properties, compost amendments have been shown to impact pesticide transport in soil. Pesticide mobility in soil can be decreased by increased sorption on compost material (Filipe et al., 2010) depending on pesticide properties and compost type. According to other authors (Yang et al., 2005 and Cabrera et al., 2007), pesticide mobility can be increased due to the higher content of dissolved organic carbon caused by soil organic matter addition. 
Dolaptsoglou et al. (2007) showed that addition of poultry compost and urban sewage sludge in a clay loam soil reduces terbuthylazine degradation compared to non-amended soils, while the addition of corn straw did not modify it. Kodešová et al. (2012) found that chlortoluron mobility in a Luvic Chernozem soil decreased up to a compost content in soil of $6 \%$, and then increased with larger compost contents ( $7 \%$ and $8 \%$ ).

Pesticide fate in soil is controlled by sorption and degradation processes that can have large spatial variability in soil at the field scale (Beck et al., 1996; Benoit et al., 1999). One of the most frequently used herbicides in European agriculture is isoproturon (IPU) [3-(4isopropylphenyl)-1,1-dimethylurea] which is used to control weeds in cereal crops (such as wheat and barley) and is one of the most detected herbicides in surface and ground waters, especially in France (SOeS, 2012). Consequently, its dynamics and fate in soil need to be clarified through laboratory and more importantly field experiments. VieubléGonod et al. (2009) conducted a research on the spatial and temporal heterogeneity of IPU biodegradation at the decimetric scale in relation to the spatial distribution of organic matter originating from urban waste compost application. Data showed that the interfurrows resulting from the incorporation of stubble and compost into the soil by plowing and located between the furrows created by the plow constituted a special local environment with the highest level of IPU mineralization. Isoproturon mineralization in the interfurrows depended on the amendment type: it was more pronounced for municipal solid waste compost than for a sewage sludge and green waste co-compost, while the control plot had the lowest mineralization rate (Vieublé-Gonod et al., 2009).

Numerical models can be used to study the effect of compost incorporation on pesticide fate in soil. Coquet et al. (2005b) used HYDRUS-2D to simulate water flow and bromide transport in a soil profile that contained compacted and non-compacted soil zones. Filipović et al. (2014) used a similar method for simulating water flow and isoproturon dynamics in a heterogeneous soil profile receiving a co-compost of sewage sludge and green wastes during a multiannual period. After calibration of the soil hydraulic parameters and optimization of the isoproturon degradation rate on a limited period of time (9 months), HYDRUS-2D was able to successfully reproduce water and isoproturon dynamics during the whole 6-year period of study.

The objective of our work was to evaluate how the application of two different types of urban compost - a municipal solid waste compost (MSW) and a sewage sludge and green waste co-compost (SGW) - to a plowed soil impacts water flow and isoproturon dynamics during a 6 year time period. The HYDRUS-2D model was used to simulate water flow and isoproturon fate in plots receiving each of these two composts and in a control plot (CONT) without compost addition.

\section{Materials and methods}

\subsection{Site and compost characteristics}

The field experiment was set up in Feucherolles (Yvelines, France) as part of the QualiAgro long-term study (Houot et al., 2002). The soil is an Albeluvisol (World Reference Base classification, IUSS, 2014) containing $19 \%$ clay, $75 \%$ silt, and $6 \%$ sand on average in its tilled layer. The soil profile was composed of five horizons which were determined on the field site: a tilled loamy LA horizon, an eluviated silt loam E horizon, an illuviated silty clay loam BT horizon, a transitional silty clay loam BT/IC horizon, and a silty loam structure-less decarbonated loess IC horizon, with some small variations in thickness of the soil horizons depending on the plot. The basic soil characteristics are presented in Table 1. The field has been cultivated since 1998 with a biannual rotation of winter wheat (Triticum spp.) and maize (Zea mays L.). Exception was made in 2006/07 when barley (Hordeum vulgare L.) was grown due to corn rootworm (Diabrotica virgifera virgifera L.) infestation. Urban waste composts were applied over wheat or barley stubble and disking was immediately carried out to incorporate composts and stubbles within the upper soil layer (first $25 \mathrm{~cm}$ ). A four-furrow moldboard plow was used for tillage every autumn

\section{Table 1}

Average soil properties for the SGW, MSW and CONT plots (mean of 4 replicate plots) ${ }^{\mathrm{a}}$.

\begin{tabular}{|c|c|c|c|c|c|c|c|c|}
\hline \multirow[t]{2}{*}{ Treatment } & \multirow{2}{*}{$\begin{array}{l}\text { Depth of soil } \\
\text { horizon } \\
(\mathrm{cm})\end{array}$} & \multirow{2}{*}{$\begin{array}{l}\text { C org } \\
\overline{\mathrm{g} \mathrm{kg}^{-1}}\end{array}$} & \multirow[t]{2}{*}{$\mathrm{C} / \mathrm{N}$} & \multirow[t]{2}{*}{$\mathrm{pH}$} & \multirow{2}{*}{$\begin{array}{l}\text { Clay } \\
\%\end{array}$} & \multirow[t]{2}{*}{ Silt } & \multirow[t]{2}{*}{ Sand } & \multirow{2}{*}{$\begin{array}{l}\text { CEC } \\
\overline{\mathrm{mol} \mathrm{kg}^{-1}}\end{array}$} \\
\hline & & & & & & & & \\
\hline \multirow{4}{*}{ SGW } & LA horizon 0-28 & 15.14 & 10.7 & 6.86 & 13.5 & 79.5 & 7.0 & 0.999 \\
\hline & Plow pan 28-38 & 11.23 & 9.8 & 6.94 & 15.5 & 78.1 & 6.4 & 0.877 \\
\hline & E horizon 38-50 & 4.78 & 8.2 & 7.15 & 21.6 & 73.5 & 4.9 & 0.991 \\
\hline & BT horizon $50-90$ & 3.20 & 7.1 & 7.29 & 29.4 & 67.1 & 3.5 & 1.425 \\
\hline \multirow[t]{4}{*}{ MSW } & LA horizon $0-28$ & 13.53 & 11.6 & 7.51 & 14.1 & 78.9 & 7.0 & 1.019 \\
\hline & Plow pan 28-38 & 11.22 & 10.2 & 7.64 & 15.9 & 78.0 & 6.1 & 0.936 \\
\hline & E horizon $38-50$ & 4.78 & 8.4 & 7.63 & 19.8 & 74.2 & 6.0 & 1.003 \\
\hline & BT horizon $50-90$ & 2.91 & 6.8 & 7.67 & 29.6 & 67.4 & 3.0 & 1.476 \\
\hline \multirow{4}{*}{ CONT } & LA horizon 0-32 & 10.12 & 10.7 & 6.63 & 14.5 & 79.0 & 6.5 & 0.738 \\
\hline & Plow pan $32-43$ & 9.20 & 9.8 & 6.84 & 17.5 & 76.2 & 6.3 & 0.773 \\
\hline & E horizon $43-50$ & 4.40 & 7.9 & 7.03 & 20.5 & 73.8 & 5.7 & 0.828 \\
\hline & BT horizon $50-90$ & 2.87 & 6.8 & 7.27 & 30.1 & 66.6 & 3.3 & 1.075 \\
\hline
\end{tabular}

a The plow layer of each of the 20 plots of the field experiment ( 5 treatments $\times 4$ repetitions - see Fig. 1a) has been sampled after the experiment in March 2010. A campaign had been dedicated to sub-layers from the 28 to $90 \mathrm{~cm}$ depth, with a similar objective, i.e., one representative sample per plot, prepared from about 30 drillings.

to a depth of $28 \mathrm{~cm}$ (plowing width of $40 \mathrm{~cm}$ ). A detailed calendar of agronomic practices can be found in Filipović et al. (2014). The field had been divided into 40 experimental plots $(45 \times 10 \mathrm{~m})$ with five treatments replicated four times in a randomized complete block design (Fig. 1a). Four different organic amendments have been applied: a municipal solid waste compost (MSW) made from residual municipal wastes after the selective collection of dry and clean packaging a biowaste compost (BIO) made from the selectively collected fermentable fractions of municipal wastes co-composted with green wastes; a compost resulting from the co-composting of sewage sludge and green wastes (SGW); and a farmyard manure (FYM) obtained from a dairy farm. These four organic treatments were compared to a control treatment (CONT) that did not receive compost amendment. The composts have been applied every second year (a supplementary compost application was made in September 2007 after the barley crop) starting 1998 in an amount of $4 \mathrm{t}$ of organic carbon per ha.

For this modeling study three plots have been selected: one plot receiving the MSW compost (average analytical characteristics for the 1998-2009 period corresponding to seven compost applications: $\mathrm{pH}_{\mathrm{MSW}}=7.4 \pm 0.4, \mathrm{OM}_{\mathrm{MSW}}=562 \pm 99 \mathrm{~g} \mathrm{~kg}^{-1}, \mathrm{C} / \mathrm{N}_{\mathrm{MSW}}=16.0 \pm$ 2.8 ), one plot receiving the SGW compost $\left(\mathrm{pH}_{\mathrm{SGW}}=7.6 \pm 0.7\right.$, $\mathrm{OM}_{\mathrm{SGW}}=454 \pm 65 \mathrm{~g} \mathrm{~kg}^{-1}, \mathrm{C} / \mathrm{N}_{\mathrm{SGW}}=10.8 \pm 2.3$ ), and a control plot. The three plots were selected close to one another (Fig. 1) for monitoring water and pesticide transport. The soil physical and chemical properties in the plowed layer $(0-28 \mathrm{~cm})$ were measured at the beginning of the agronomic experiment in 1998 (Table 2) and confirmed the homogeneity of the field site. In addition, an electrical resistivity prospection has been performed in 2004 (Fig. 1b) and showed that the field site was homogeneous and that the largest variations of apparent electrical resistivity were found at the edges of the field. The selected plots had similar ranges of electrical resistivity variation.

In December 2004 large soil pits ( $45 \mathrm{~cm}$ deep and $2 \mathrm{~m}$ wide) were dug in each of the three plots and were described according to Manichon's (1982) method (Fig. 2). This method is used to describe the soil structure of the tilled layer of agricultural fields. It is based on the visual observation of soil macroscopic features on the vertical face of a large soil pit oriented perpendicular to the tillage direction (Coutadeur et al., 2002; Roger-Estrade et al., 2000). The soil profile was divided into vertical and horizontal compartments according to the effects of the tillage implements and the internal structure of each of these compartments. Three types of compartments were distinguished in the tilled layer (Fig. 2):

- The furrows - correspond to the soil which has been cut and rotated by the moldboard plow. Macroporous soil zones, noted $\Gamma$, and 




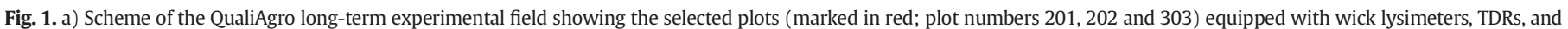

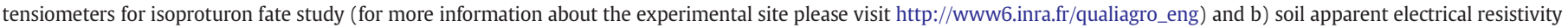
survey map of the field site (0-100 cm depth) performed in February 2004.

compacted soil zones, noted $\Delta$ could be distinguished within these furrows. Soil in the $\Delta$ zones had smoothly breaking faces and no structural porosity. Such compacted soil zones were initially located below wheel tracks and had been displaced by plowing. The $\Gamma$ structure is formed by the assembly of macroporous aggregates or clods, with clearly visible structural porosity.

- The interfurrows (IF) - located between the furrows created by the moldboard plow. IF contained a large amount of organic matter originating from the plant residues of the preceding crop (SGW, MSW, CONT) and from compost application (SGW, MSW). They were characterized by a structural porosity clearly visible by the eye and by a large amount of organic residues.

- An additional layer corresponding to a plow pan (PP) was identified between the tilled layer and underlying untilled $\mathrm{E}$ horizon from 28 to $\sim 38 \mathrm{~cm}$. This layer was characterized by a continuous $\Delta$ structure and resulted from long-term plowing to the same depth.

\subsection{Field and laboratory measurements}

Pressure head was measured in the three plots using tensiometers (SDEC, France) installed at the 20, 40,60, 80, 100, 130, and 160-cm depth during 2007/08. Water content was measured from 2004 to 2010 using Time Domain Reflectometry (TDR) probes (Trase system, Soil Moisture Equipment Corp., CA, USA) installed at the 20, 40, 60, 80, and 100-cm depth. Gravimetric water contents were measured on soil samples taken with an auger at multiple dates during 2007/2008 and were used for TDR calibration. Meteorological daily data (rainfall, air temperature, air humidity, wind speed, and net radiation) were collected at a meteorological station located near the field experiment (at $500 \mathrm{~m}$ ). Two passive capillary-wick lysimeters ( $25 \mathrm{~cm} \times 25 \mathrm{~cm}$, constructed by INRA, Grignon) were installed at the $45-\mathrm{cm}$ depth. In each plot two lysimeters were installed one beside another to ensure more reliable results (in our

Table 2

Average soil characteristics of the tilled layer $(0-28 \mathrm{~cm})$ at the beginning of the field experiment in 1998 in the three selected plots (SGW, MSW, and CONT).

\begin{tabular}{|c|c|c|c|c|c|}
\hline \multirow[t]{2}{*}{ Treatment } & C org & $\mathrm{C} / \mathrm{N}$ & $\mathrm{pH}$ & Clay & CEC \\
\hline & $\overline{\mathrm{g} \mathrm{kg}^{-1}}$ & & & $\%$ & $\mathrm{~mol} \mathrm{~kg}^{-1}$ \\
\hline SGW & 9.91 & 9.62 & 7.20 & 13.5 & 0.922 \\
\hline MSW & 11.01 & 10.39 & 7.20 & 14.1 & 0.962 \\
\hline CONT & 10.39 & 9.54 & 7.00 & 14.5 & 0.923 \\
\hline
\end{tabular}

study we have used the average values from the two lysimeters). Fiberglass wicks (Peperell, 1/2 inch) of 70 -cm height were untwisted and mounted on a stainless steel plate that was installed horizontally under the undisturbed soil. Leachate was collected through the wick lysimeters, filtered at $0.45 \mu \mathrm{m}$ and stored at $4{ }^{\circ} \mathrm{C}$ prior to chemical analysis. Isoproturon concentration was measured by the Institut Pasteur (Lille, France) using online SPE-LC-MS-MS (QUATTRO Premium 2005; NF EN ISO 11369). The quantification limit was $0.02 \mu \mathrm{g} \mathrm{L}-1$. Near-saturated soil hydraulic conductivity was calculated from steady state infiltration rates at five soil water potentials $(-0.6,-0.4,-0.2,-0.125$ and $-0.05 \mathrm{kPa}$ ) measured in each plot for each type of soil structure using a tension disk infiltrometer (SDEC, France) with a $4 \mathrm{~cm}$-diameter base (Schneider et al., 2009). The base size was chosen because of the small lateral dimensions of some of the soil zones to be characterized (e.g., interfurrows). Water retention values were measured in the laboratory using Richards' pressure plate apparatus (Klute and Dirksen, 1986) on $50 \mathrm{~cm}^{3}$ soil samples taken from each plot and soil structure type applying pressures of $1,3,10,30,100,310,1000$ and $1580 \mathrm{kPa}$, successively. The van Genuchten $\theta_{r}, \alpha$, and $n$ parameters of the soil water retention curve were optimized using the RETC software (van Genuchten et al., $1991) . R^{2}$ values varied from 0.81 to 0.99 . The bulk density was determined from samples taken horizontally from each soil observation face using cylinders of $2.5 \mathrm{~cm}$ diam. and $4 \mathrm{~cm}$ length. The soil was systematically sampled at the nodes of a rectangular grid $(0.36 \mathrm{~m}$ height, $1 \mathrm{~m}$ width) with $4-\mathrm{cm}$ mesh. Soil organic carbon and $\mathrm{N}$ contents were determined using a Carlo Erba Elemental Analyser NA 1500 Series 2 on airdried $2 \mathrm{~mm}$-sieved homogenized samples made up from 10 to 15 individual samples taken from each soil zone.

\subsection{Isoproturon sorption and degradation parameters}

Sorption coefficients, $K_{d}$, of IPU (Table 3) were measured by Pot et al. (2011) for each morphological zone $\left(\Gamma, \Delta\right.$, IF, PP) in batch using a ${ }^{14} C$ isoproturon solution prepared at $0.51 \mathrm{mg} \mathrm{L}^{-1}$ in calcium chloride (0.01 M). Each sorption coefficient was calculated as:

$K_{d}=\frac{s}{c}$

where $c\left(\mathrm{mg} \mathrm{L}^{-1}\right)$ and $s(-)$ are the solution and sorbed concentration, respectively, obtained after $24 \mathrm{~h}$ equilibrium.

In January and May 2005, ${ }^{14} \mathrm{C}$-isoproturon mineralization was followed under laboratory controlled conditions $\left(28{ }^{\circ} \mathrm{C}, 80 \%\right.$ of 


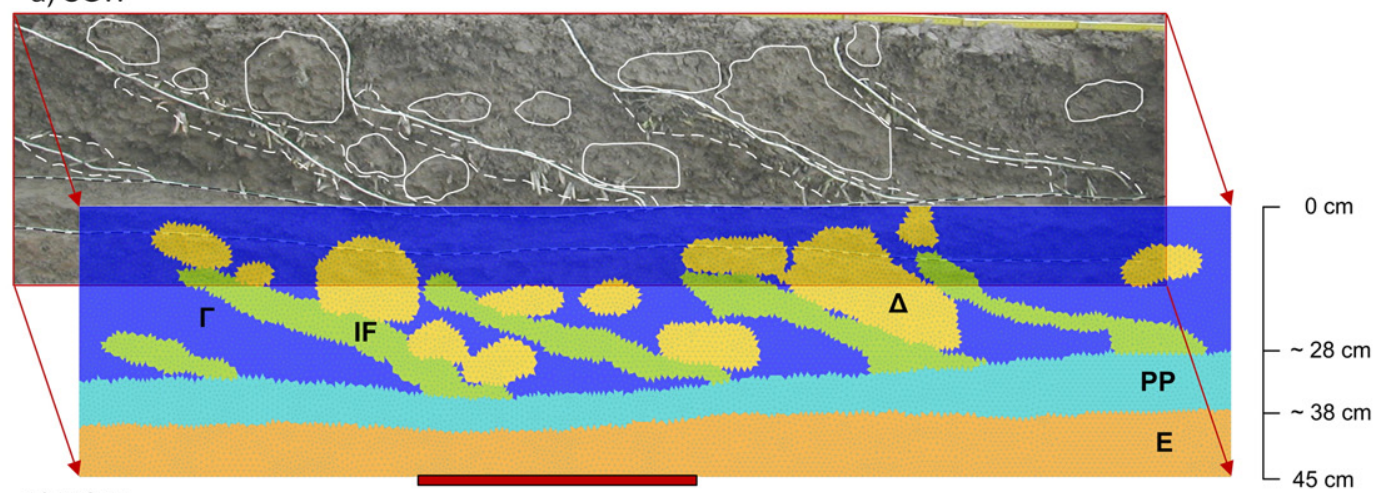

b) MSW

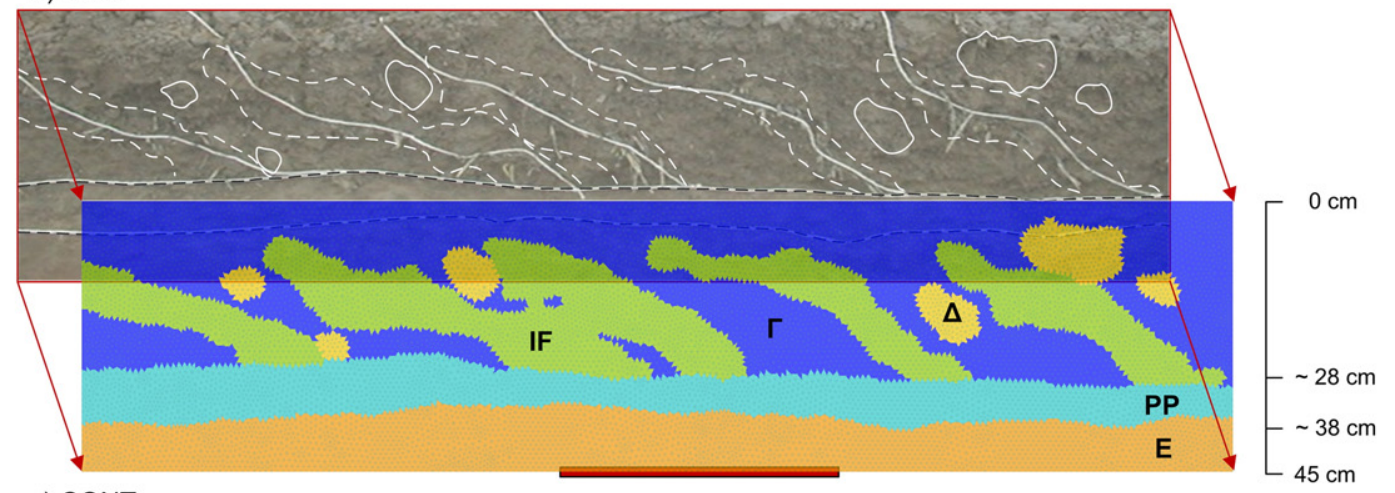

c) CONT

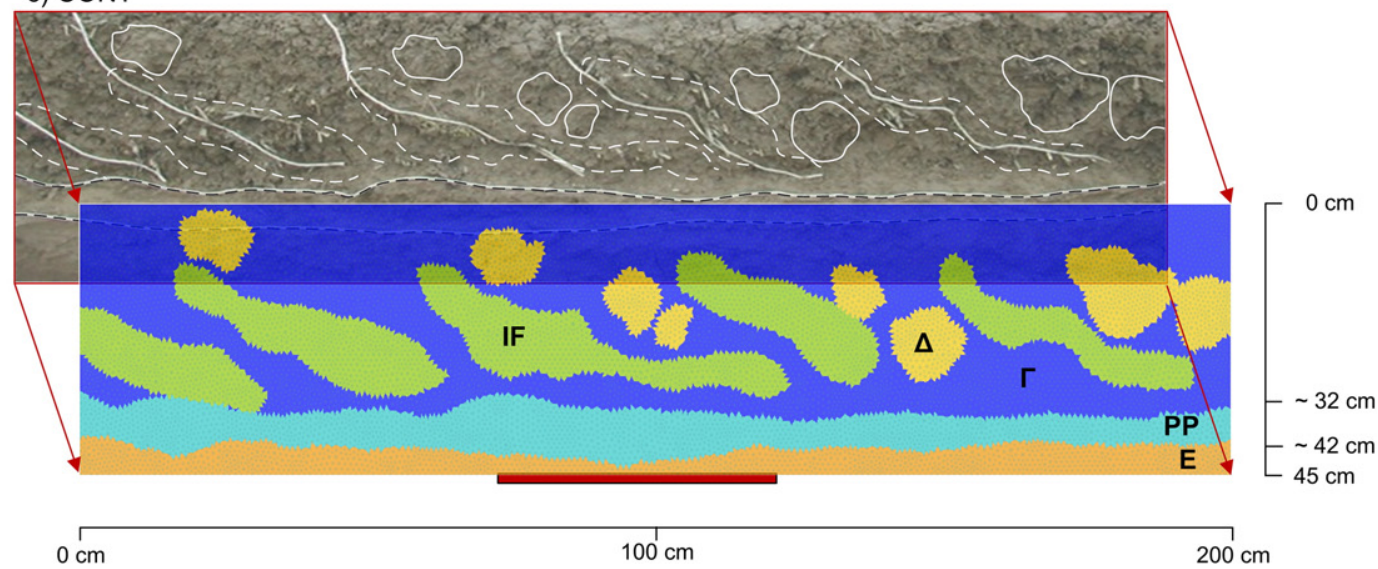

Fig. 2. Field description of the plots receiving either a sewage sludge and green waste co-compost (SGW) or a municipal solid waste compost (MSW) and the control plot without compost addition (CONT), showing the different soil structures observed in the first $45 \mathrm{~cm}$ depth together with their spatial distribution in the HYDRUS-2D model and the location of the wick lysimeters. Identified structures are: the non-compacted soil ( $\Gamma$, blue), the compacted soil ( $\Delta$, yellow), the interfurrows (IF, green), the plow pan (PP, light blue), and the $\mathrm{E}$ horizon (orange).

water content at $\mathrm{pF}=2.5$ ) during 65 days. Trapping solutions were analyzed for ${ }^{14} \mathrm{C}-\mathrm{CO}_{2}$ concentrations by adding $10 \mathrm{~mL}$ of scintillating liquid (Ultima Gold XR, Packard) and counting $10 \mathrm{~min}$ in a Tri-Carb 2100TR scintillation counter (Perkin Elmer Ins., Courtaboeuf, France). Isoproturon degradation rates were calculated from ${ }^{14} \mathrm{C}$ isoproturon mineralization for each soil structure of each of the three plots. More details about the degradation study can be found in Vieublé-Gonod et al. (2009).

\subsection{Modeling}

\subsubsection{Water flow and solute transport equations}

Water flow and isoproturon transport were simulated using the HYDRUS-2D software (Šimůnek et al., 2008). Water flow was modeled using Richards' equation:

$\frac{\partial \theta}{\partial t}=\frac{\partial}{\partial x_{i}}\left[K\left(K_{i j}^{A} \frac{\partial h}{\partial x_{i}}+K_{i z}^{A}\right)\right]-S$

where $\theta$ represents the volumetric water content $\left[\mathrm{L}^{3} \mathrm{~L}^{-3}\right], h$ is the pressure head $[\mathrm{L}], x_{i}(\mathrm{i}=1,2)$ are the spatial coordinates $[\mathrm{L}], t$ is the time $[\mathrm{T}]$, $K_{i j}^{A}$ are the components of the dimensionless hydraulic conductivity anisotropy tensor $\left(K^{A}\right)$ in the two main spatial direction $x_{i}(\mathrm{i}=1,2)$ with $x_{1}=x$ and $x_{2}=z, K$ is the unsaturated hydraulic conductivity [ $\left.\mathrm{L} \mathrm{T}^{-1}\right]$, and $S$ represents the root water uptake $\left[\mathrm{L}^{3} \mathrm{~L}^{-3} \mathrm{~T}^{-1}\right]$. The diagonal entries of $K_{i j}^{A}$ equal to one and the off-diagonal entries zero for an isotropic medium. 


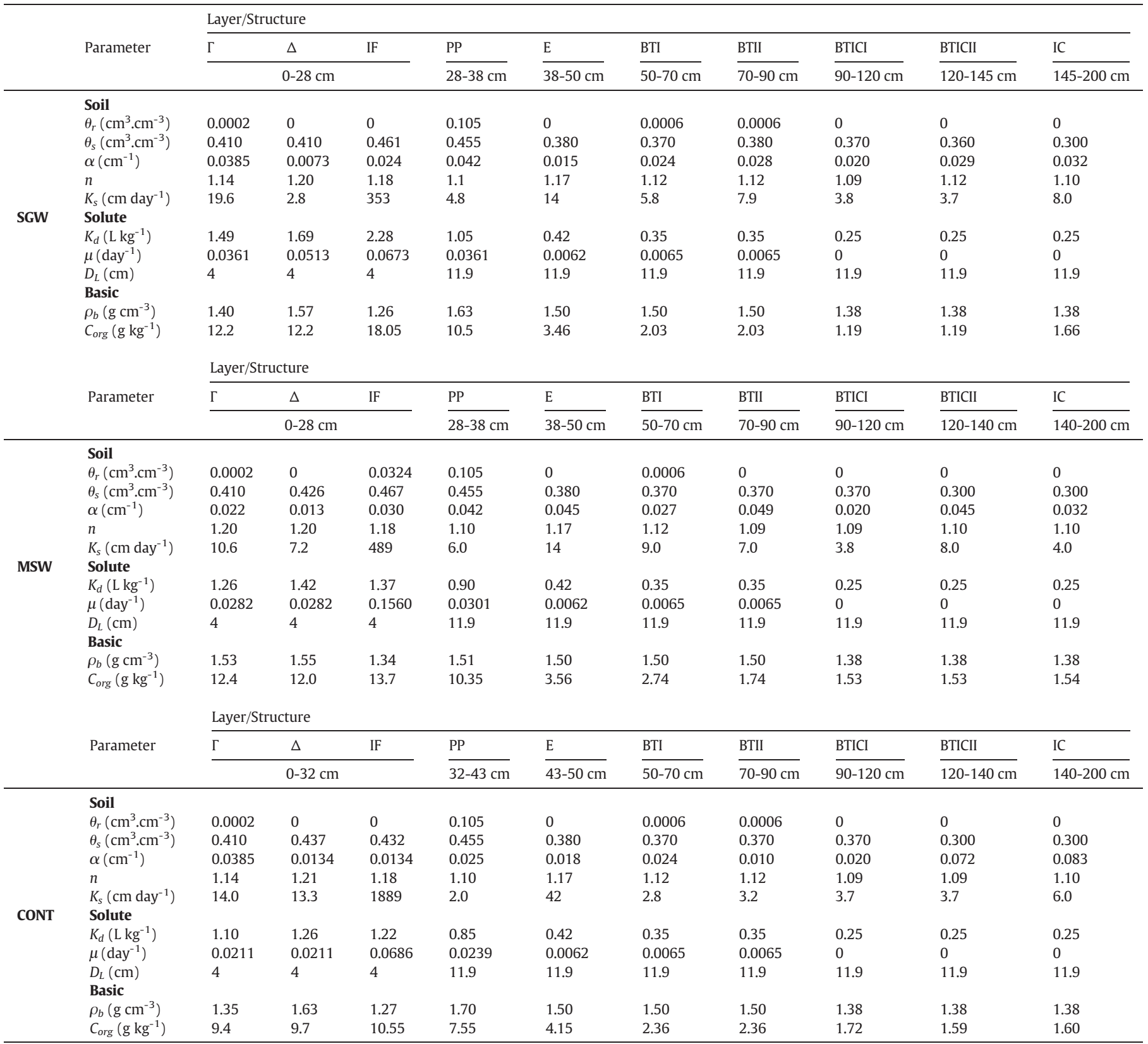

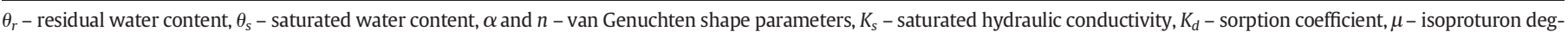
radation rate in liquid phase, $D_{L}$ - longitudinal dispersivity, $\rho_{b}$ - bulk density, $C_{\text {org }}$ - organic carbon content.

Solute transport was modeled using the advection-dispersion equation assuming first order kinetics for solute degradation in the liquid phase and instantaneous and linear sorption onto soil solid surfaces (Eq. (1)):

$\frac{\partial(R \theta c)}{\partial t}=\frac{\partial}{\partial x_{i}}\left(\theta D_{i j} \frac{\partial c}{\partial x_{i}}\right)-\frac{\partial\left(q_{i} c\right)}{\partial x_{i}}-\mu \theta c$

where $c$ is the solute concentration in the liquid phase $\left[\mathrm{M} \mathrm{L}^{-3}\right], q_{i}$ is the $i$ th component of the volumetric water flux density $\left[\mathrm{L} \mathrm{T}^{-1}\right], D_{i j}$ are the components of the dispersion coefficient tensor $\left[\mathrm{L}^{2} \mathrm{~T}^{-1}\right], \mu$ is the first-order degradation rate in the liquid phase $\left[\mathrm{T}^{-1}\right]$, and $R$ is the retardation factor [-] written as:

$$
R=1+\frac{\rho_{b} K_{d}}{\theta}
$$

where $\rho_{b}$ represents soil bulk density [ $\left.\mathrm{M} \mathrm{L}^{-3}\right]$.

Degradation was assumed to be water content and temperature dependent, assuming Walker's (with an exponent value of 0.38) and $\mathrm{Ar}$ rhenius' expressions (with an activation energy for degradation of $45 \mathrm{KJ} \mathrm{mol}^{-1}$ ). 
Soil hydraulic functions $\theta(h)$ and $K(h)$ were described using the van Genuchten-Mualem model (van Genuchten, 1980), which is defined as follows:

$\theta(h)=\theta_{r}+\frac{\theta_{s}-\theta_{r}}{\left(1+|\alpha h|^{n}\right)^{m}}$ for $\mathrm{h}<0$

$\theta(h)=\theta_{s}$ for $h \geq 0$

$K(h)=K_{s} S_{e}^{l}\left(1-\left(1-S_{e}^{\frac{1}{m}}\right)^{m}\right)^{2}$

$S_{e}=\frac{\theta-\theta_{r}}{\theta_{s-} \theta_{r}}$

$m=1-\frac{1}{n} ; \mathrm{n}>1$ where $\theta_{\mathrm{r}}$ and $\theta_{\mathrm{s}}$ denote residual and saturated volumetric water content $\left[\mathrm{L}^{3} \mathrm{~L}^{-3}\right]$, respectively, $K_{s}$ is the saturated hydraulic conductivity $\left[\mathrm{L} \mathrm{T}^{-1}\right]$, $S_{e}$ is the effective saturation, $\alpha\left[\mathrm{L}^{-1}\right]$ and $n[-]$ are the shape parameters, and $l[-]$ is a pore connectivity parameter. The pore connectivity parameter value was taken from an average for many soils $(l=0.5)$ (Mualem, 1976). A modified van Genuchten (1980) model with an air-entry value of $2 \mathrm{~cm}$ was used in all simulations.

\subsubsection{Simulation domain, initial and boundary conditions}

A two-dimensional square domain $(200 \times 200 \mathrm{~cm})$ was used to simulate water flow and solute transport using HYDRUS-2D. The material distribution in the tilled (LA) layer and in the deeper layers (E, BT, BT/ IC, IC) was determined according to field observations (Fig. 2). Although the soil was tilled every year, the material distribution in the tilled layer was kept constant. This choice was supported by the fact that the overall structure of the tilled layer reaches a steady state within a few years
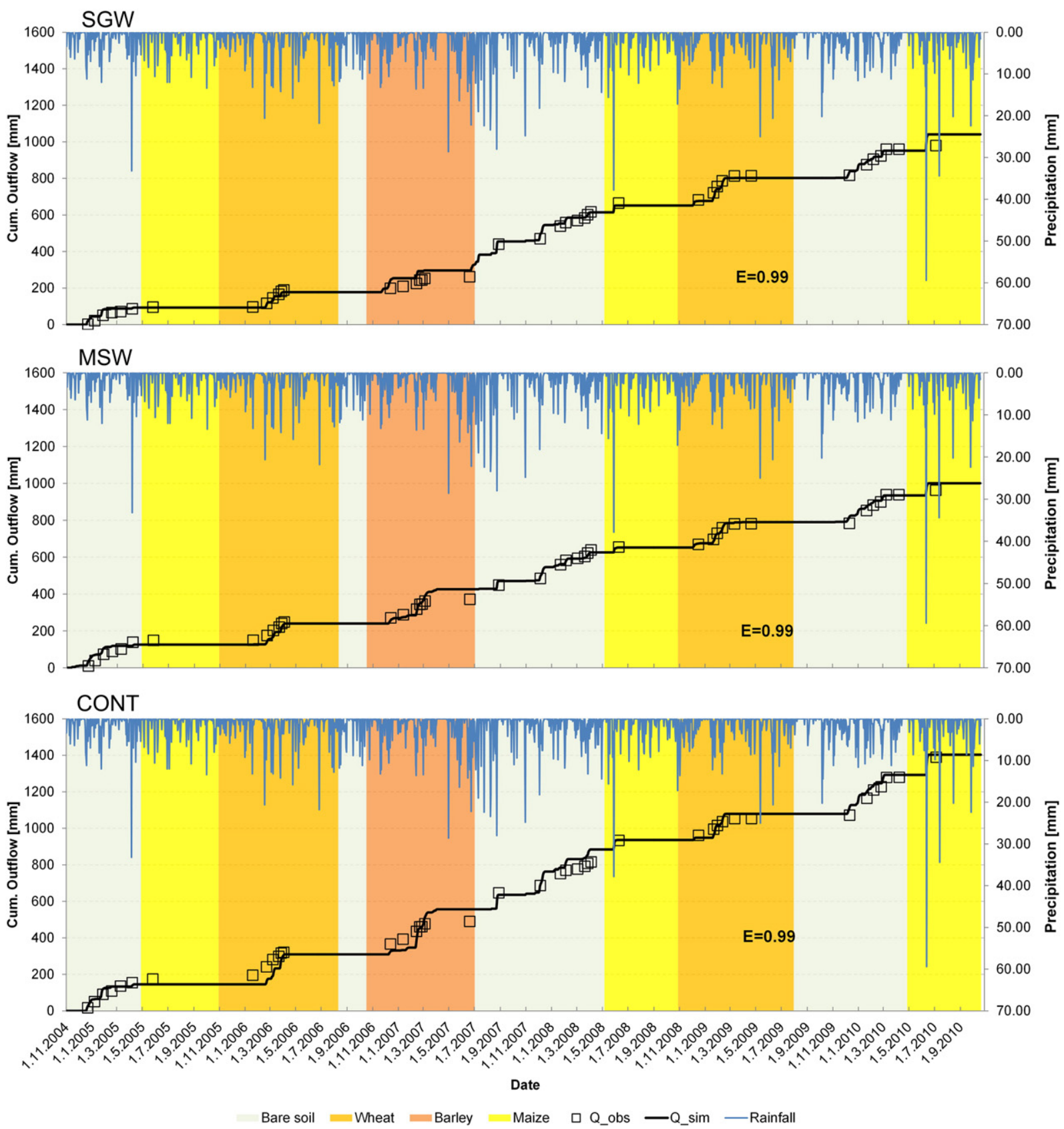

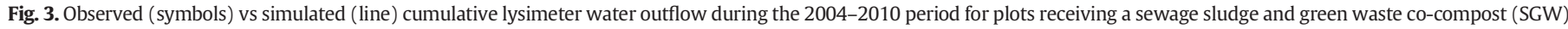
or a municipal solid waste compost (MSW) and a control plot without compost addition (CONT). 
under constant agricultural practices (Roger-Estrade et al., 2000) which was the case in the current experiment. The BT and BT/IC horizons were divided into two layers in order to correspond with the field measurements (TDR, tensiometers) installed at two different depths within these horizons. The initial condition for water was set as hydrostatic pressure head distribution with $-100 \mathrm{~cm}$ at the bottom of the soil profile. Initial isoproturon concentration in the whole soil profile was set to zero corresponding to the measured lysimeter leachate concentration before the start of the study. An atmospheric boundary condition was selected at the top of the soil profile and a free drainage boundary condition was selected at the bottom. A seepage face boundary condition with a suction of $-70 \mathrm{~cm}$ was applied at the lysimeter plate. Third type solute boundary conditions were selected for isoproturon transport at top, bottom and lysimeter plate boundaries. More details about the modeling method can be found in Filipović et al. (2014). Initial soil hydraulic parameter values were defined using pressure plate and tension infiltrometer data (see Section 2.2) for water transport, and using sorption and degradation data (see Section 2.3) for isoproturon transport. Soil hydraulic parameters were manually calibrated on water content, matric potential and lysimeter outflow data for a limited period of time (from 24 January to 27 October 2008).

To evaluate the numerical simulations, coefficient of determination $\left(R^{2}\right)$ and model efficiency coefficient (E) (Nash and Sutcliffe, 1970) were calculated. The model efficiency coefficient $(E$, Eq. (9)) determines the relative magnitude of the residual variance compared to the observed data variance:

$E=1-\frac{\sum_{i=1}^{n}\left(O_{i}-S_{i}\right)^{2}}{\sum_{i=1}^{n}\left(O_{i}-O\right)^{2}}$

where $O_{i}$ and $S_{i}$ represent the observed and simulated values, respectively, $O$ represent the average of observed values, and $n$ is the number of observed/simulated points.

The coefficient of efficiency varies between $-\infty$ and 1 , where 1 indicates a perfect model.

\section{Results and discussion}

\subsection{Water flow}

Calibration of soil hydraulic parameters was performed after an initial simulation run using measured soil hydraulic parameters $\left(\theta_{\mathrm{s}}, \theta_{\mathrm{r}}, \alpha, n\right.$, $K_{s}$ ) did not reproduce any outflow. The large measured values of the saturated hydraulic conductivities of the upper soil layers, especially the $\mathrm{E}$ horizon, caused water to percolate down to the deeper soil instead of going into the lysimeter plates. The largest differences between the initially measured parameters (not shown here) and the calibrated ones were found for the $K_{s}, \alpha$, and $n$ parameters of each structure/layer. After calibration, the interfurrows had the largest $K_{s}$ values (Table 3).
A)
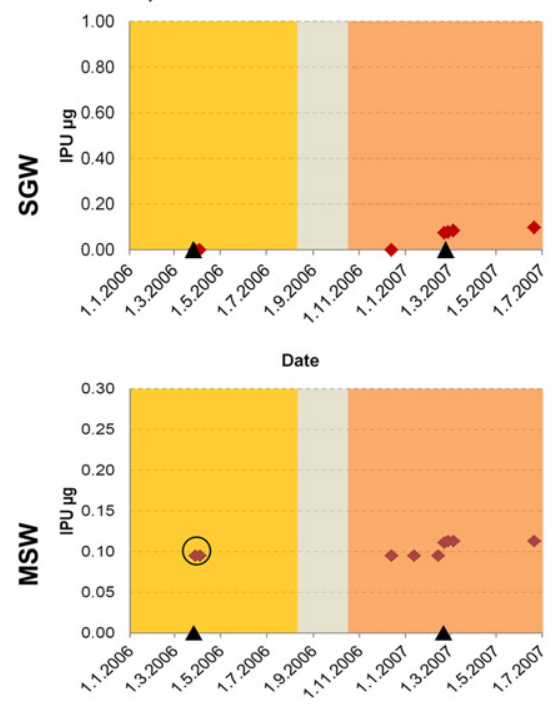

Date

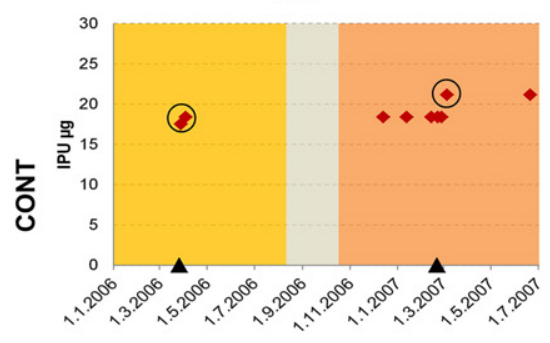

B)

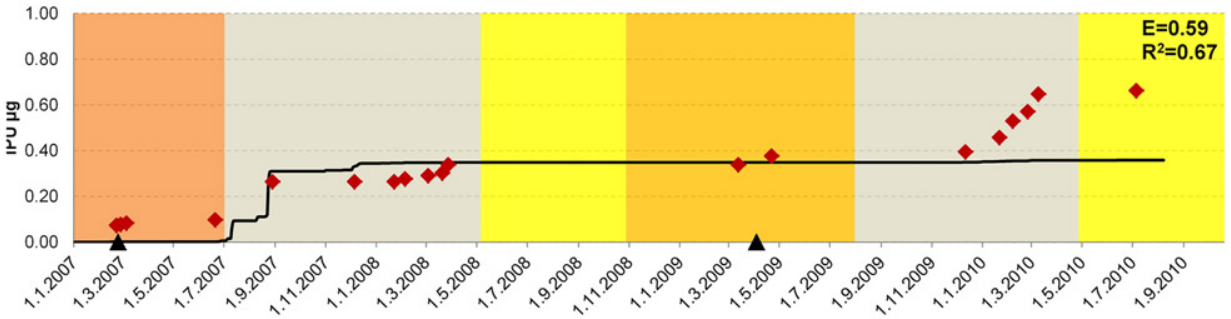

Date

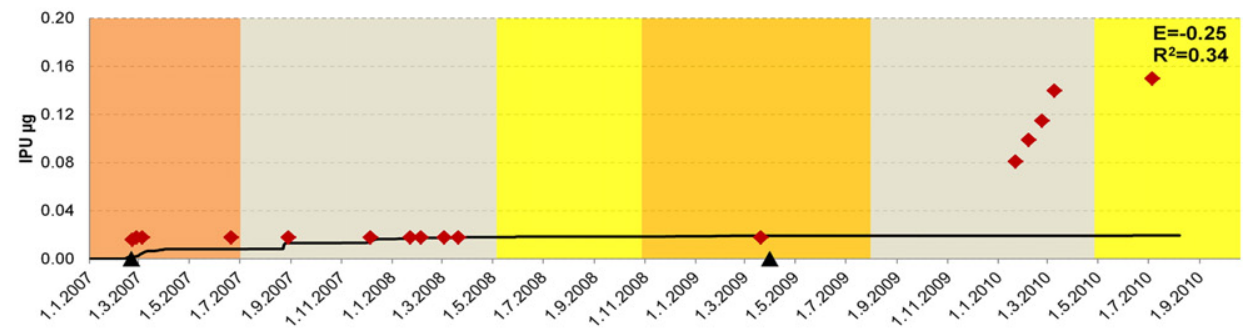

Date

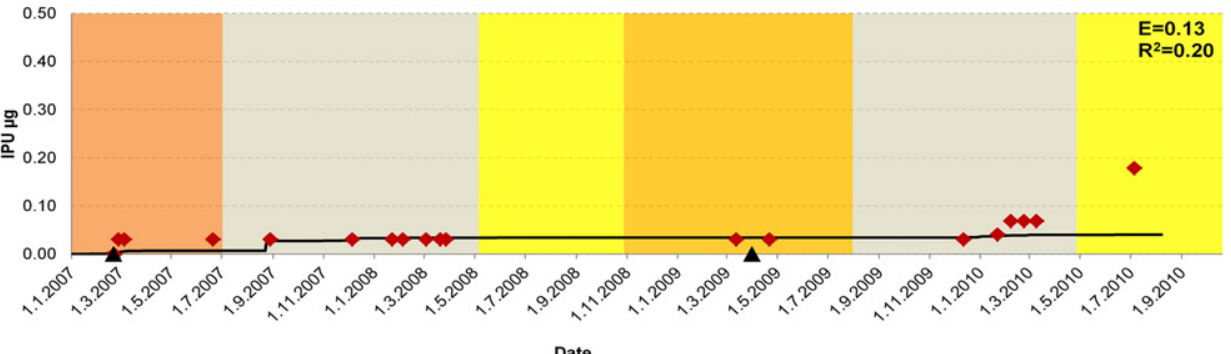

Date

Bare soil Maize Wheat $=$ Barley - IPU obs -IPU sim $\Delta$ IPU applic.

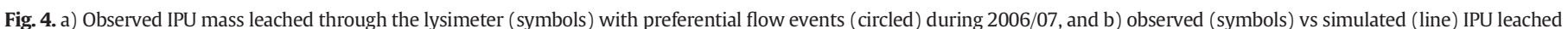

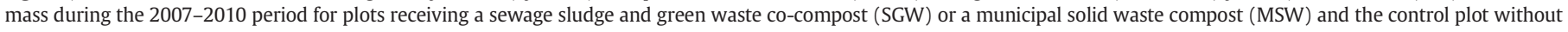
compost addition (CONT). IPU applications are indicated as triangles on the time axis. 
Compost application increased organic $\mathrm{C}$ contents in both compost amendment plots compared to the control plot (Table 3 ). This is visible in the whole tilled layer where increased values are found for all three structure types $(\Gamma, \Delta$, and IF). The largest organic $C$ contents were observed in the interfurrows of the plots that received compost. The difference in organic $C$ content between the IF and the $\Gamma$ and $\Delta$ structures was smaller in the control plot because the IF did not contain any compost material. Lower bulk density was measured in all three plots in the interfurrow zones. The largest simulated water content values were found in the interfurrow zones for all three plots during the whole 6 year period, which could be related to the high organic matter content of these zones which caused increased water retention. A detailed study of the effect of compost application on soil organic $C$ content and bulk density can be found in Schneider et al. (2009) and Houot et al. (2009). The calibrated model showed better agreement in cumulative water outflow for the SGW $(E=0.79)$ and MSW plots $(E=0.88)$ than for the CONT plot $(E=0.13$ ) over the 2008 calibration period. Observed volumetric water contents were fitted satisfactorily $\left(\mathrm{E}_{\mathrm{SGW}}=\right.$ 0.50 to $0.98, \mathrm{E}_{\mathrm{MSW}}=0.15$ to $0.86, \mathrm{E}_{\mathrm{CONT}}=0.62$ to 0.93 , depending on the soil layer) as well as pressure heads ( $\mathrm{E}_{\mathrm{SGW}}=0.06$ to 0.87 , $\mathrm{E}_{\mathrm{MSW}}=0.0012$ to $0.90, \mathrm{E}_{\mathrm{CONT}}=0.17$ to 0.90 ). Water flow was then simulated from the 1st of November 2004 until the 19th of October 2010 using the sets of calibrated soil hydraulic parameters derived from the 9-month calibration period (Table 3). After small LAI modifications on the 2006/07 wheat and 2007 barley crops (Filipović et al., 2014), water flow simulations showed very good agreement with the measured water outflow data in all three plots with model efficiency values of 0.99 (Fig. 3). Similar cumulative water outflows were found in the SGW and MSW plots (979 $\mathrm{mm}$ and $962 \mathrm{~mm}$ ), while the CONT plot showed a larger value (1388 mm). On the long term (6 years), compost

a)

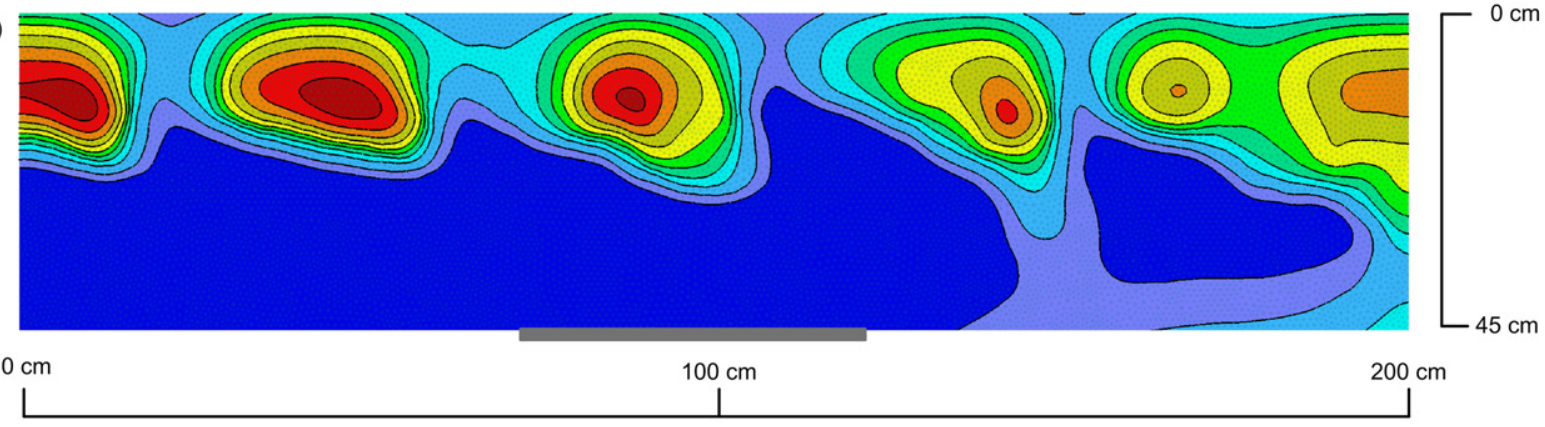

$\begin{array}{llllllllllll}0.0 & 1.0 \mathrm{e}-7 & 2.0 \mathrm{e}-7 & 4.0 \mathrm{e}-7 & 6.0 \mathrm{e}-7 & 8.0 \mathrm{e}-7 & 1.0 \mathrm{e}-6 & 1.25 \mathrm{e}-6 & 1.5 \mathrm{e}-6 & 1.75 \mathrm{e}-6 & 2.0 \mathrm{e}-6 & 2.2 \mathrm{e}-6\end{array}$

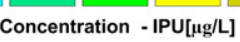

b)

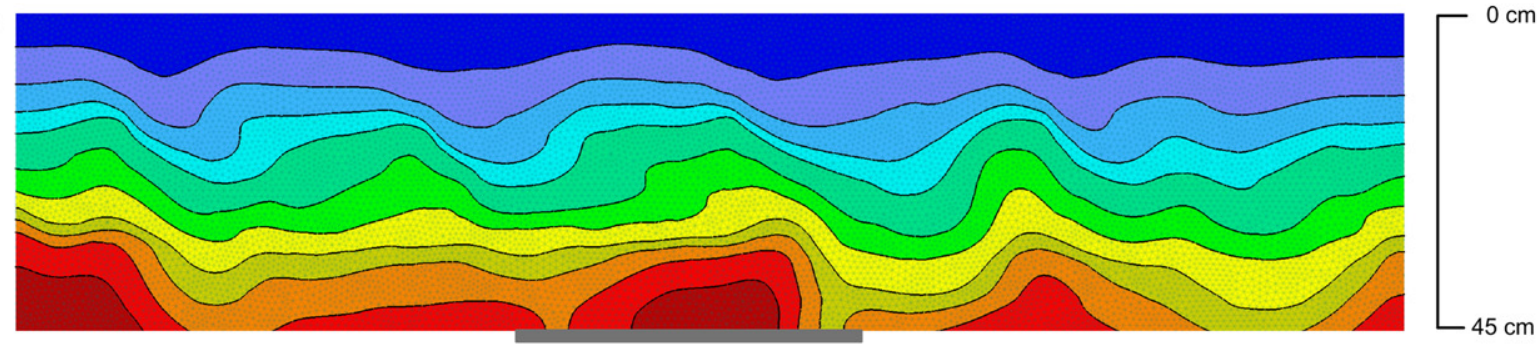
$0 \mathrm{~cm}$

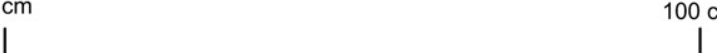

$200 \mathrm{~cm}$

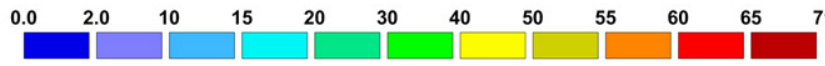

Concentration - $\mathrm{Br}[\mu \mathrm{g} / \mathrm{L}]$

c)
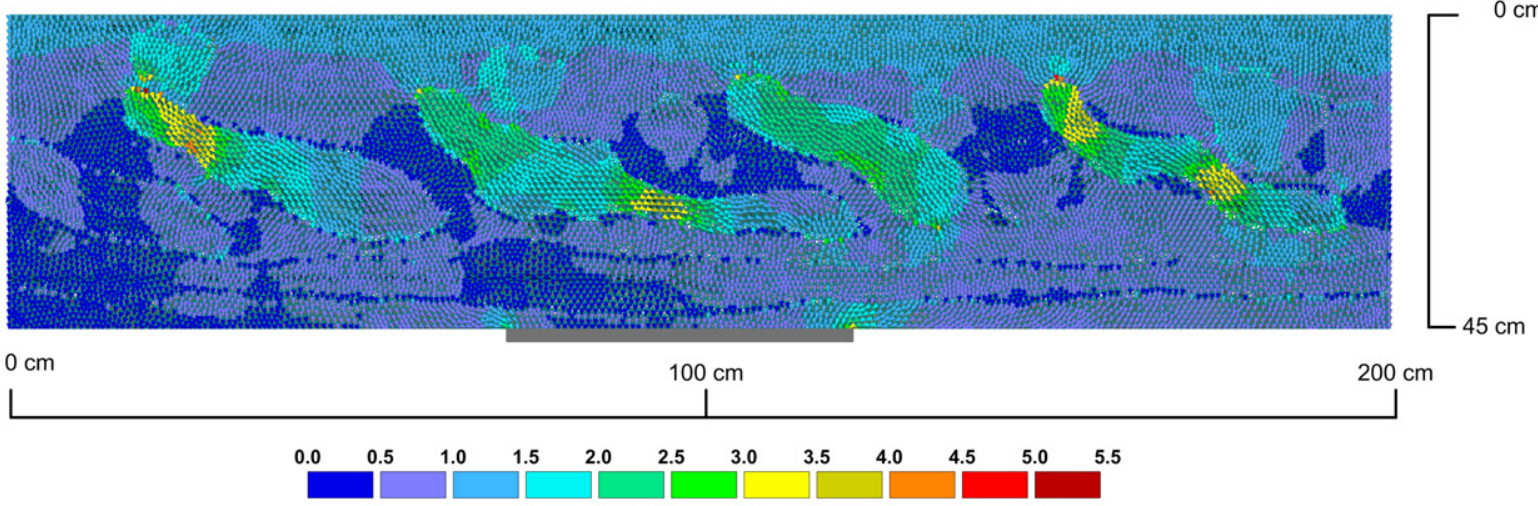

Velocity $-\mathrm{v}[\mathrm{cm} /$ day $]$

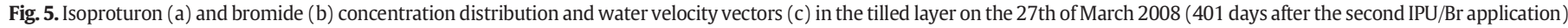
in the control plot without compost addition (CONT). 
application tended to limit downward water flow. This result can be related to the fact that compost application decreases hydraulic conductivity at high pressure heads in the tilled layer (Schneider et al., 2009). The IF $K_{s}$ in the CONT plot was approximately 4.5 times higher than in the compost-amended plots. Water velocity maps showed large differences between soil zones. On the 7th of October 2007 (after $33.2 \mathrm{~mm}$ of rainfall within the previous $48 \mathrm{~h}$ ), the maximum water velocity in the SGW plot was $8 \mathrm{~cm}_{\text {day }}{ }^{-1}$ in the IFs compared to $2 \mathrm{~cm}_{\text {day }}{ }^{-1}$ in the $\Gamma$ zones. In the MSW plot, maximum water velocity was $7.5 \mathrm{~cm}$ day $^{-1}$ in the IFs compared to $1.4 \mathrm{~cm}$ day $^{-1}$ in the $\Gamma$ zones, and in the CONT plot maximum water velocity was $10 \mathrm{~cm}_{\text {day }}{ }^{-1}$ in the IFs compared to $3 \mathrm{~cm} \mathrm{day}^{-1}$ in the $\Gamma$ zones. Water content simulations also showed good agreement with measured values for the 20042010 period, although the quality of the agreement varied among soil layers $\left(\mathrm{E}_{\mathrm{SGW}}=0.23-0.92, \mathrm{E}_{\mathrm{MSW}}=0.18-0.89, \mathrm{E}_{\mathrm{CONT}}=0.42-0.89\right.$ ) which could be a result of the variability in time of the soil hydraulic properties (Alletto et al., 2015). However, HYDRUS-2D was able to model water flow with high accuracy during a 6-year period from 2004 to 2010 in the SGW, MSW and CONT plots after calibration on a 9-month period only, without considering any change in the structure of the plowed layer or in its hydraulic properties with time.

\subsection{Isoproturon fate modeling}

Measurements of IPU leaching through the lysimeter plates showed differences between the three selected plots. However, due to the lack of replicated experimental plots because of their cost there is a possibility that the observed differences might be driven by differences in the studied plots although basic soil characteristics were not found to be different among the plots (Table 1, Fig. 1b). The cumulated IPU mass collected with the lysimeter plates during the 2004-2010 period was $0.663,0.245$, and $21.31 \mu \mathrm{g}$ for the SGW, MSW, and CONT plots, respectively. These differences suggest that compost amendments can limit pesticide mobility in soils, which is consistent with the higher IPU sorption coefficient and degradation rate found in the compost-amended plots (Table 3). There was evidence of preferential flow events in the MSW plot during 2006 and in the CONT plot during 2006 and 2007, but not in the SGW plot (Fig. 4a). Three IPU applications have been performed during the studied period, on March 23, 2006, February 20, 2007, and March 31, 2009. In the MSW plot, an IPU leaching of $0.095 \mu \mathrm{g}$ (38\% of total IPU leached) was measured 5 days after the first IPU application (Fig. 4a). In the CONT plot, $17.5 \mu \mathrm{g}$ of IPU was leached ( $82 \%$ of total IPU leached) on the same date corresponding to a
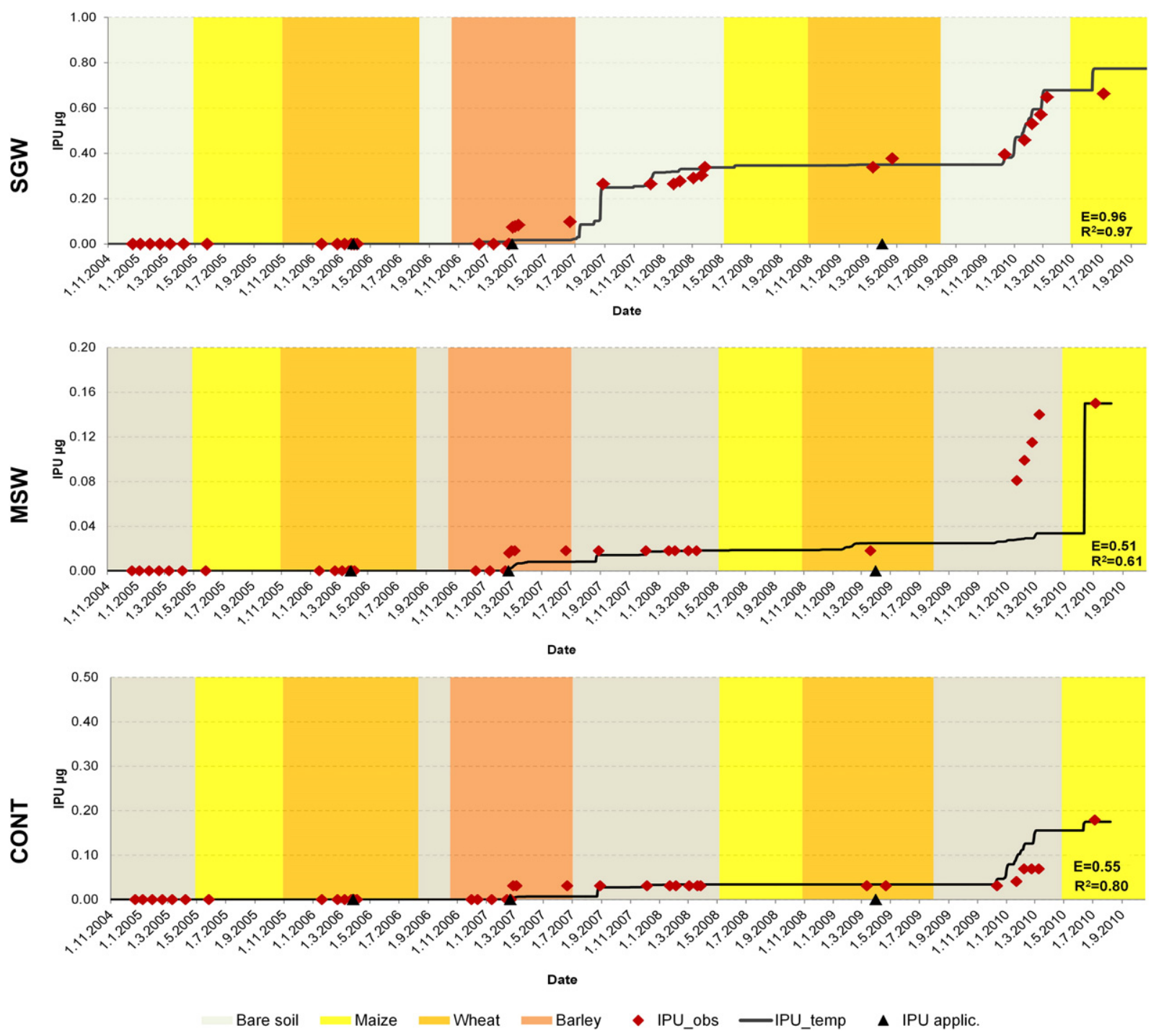

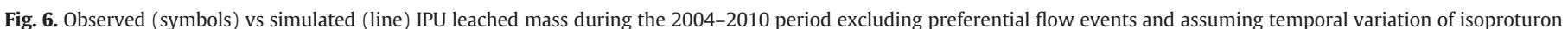


(CONT). IPU applications are indicated as triangles on the time axis. 
$37 \mathrm{~mm}$ water outflow promoted by high intensity rainfall events after the first application. On April 4th 2006, an IPU mass of $0.86 \mu \mathrm{g}$ was also leached (4\% of total IPU leached) in the CONT plot. Finally, $2.73 \mu \mathrm{g}$ (13\% of total IPU leached) was measured in the leachate 13 days after the second IPU application in the CONT plot. The large values of IPU mass leached short after application suggests preferential flow events. These IPU leaching events could not be reproduced by HYDRUS-2D (Fig. 4b) based on the optimized hydraulic parameters and the laboratory-measured sorption and degradation parameters. Additional simulations were carried out using bromide ( $\mathrm{Br}$ ) instead of IPU (no sorption or degradation was considered). These simulations displayed peak positions of $\mathrm{Br}$ leaching just after its application for the MSW and CONT plots during the 2006-07 period. However the cumulated $\mathrm{Br}$ mass leached after the first application on April 5, 2006 was $0.2 \%$ of total simulated $\mathrm{Br}$ leached ( $94 \mu \mathrm{g}$ and $130 \mu \mathrm{g}$ in the CONT and MSW plots respectively), which remained very small compared to the percentage of measured IPU mass leached in both plots (86 and 38\% for CONT and MSW respectively). The amount of $\mathrm{Br}$ leached and the time of leaching simulated right after the first and second applications suggested that the proposed 2D model parameterization with a detailed spatial description of soil heterogeneity was able to reproduce rapid flow through the IF zones only partially. Additional macropore preferential flow is thus suggested to explain the high measured IPU mass leached in the three events (Fig. 4a). The simulated $\mathrm{Br}$ (not shown) and IPU concentration breakthrough curves had clearly different leaching times with IPU delayed compared to $\mathrm{Br}$ peaks. This difference may be explained by the sorption coefficients and degradation rates assigned to the different soil zones, especially for the IF which had large values of IPU degradation rate and sorption coefficient thus causing low or no IPU mass in the outflow and/or a delay due to IPU sorption. Fig. 5 presents the concentration distribution of IPU and $\mathrm{Br}$ in the tilled layer along with the velocity vector map in the CONT plot. The difference in concentration pattern and magnitude is a direct result of the sorption and degradation processes applying to IPU. The snapshot was selected on a day with $13.2 \mathrm{~mm}$ of rainfall (27th of March 2008), which generated a $10.3 \mathrm{~mm}$ simulated water outflow and resulted in high velocity flows. Velocity vectors indicate that most of the high flow values occurred in the IF zones, and that $\Delta$ clods were either bypassed or that they directed the flow towards more permeable IF zones (compare Fig. 5 to Fig. 2). These results supported the observation that IF zones played a significant role in IPU transport during high intensity rainfalls following application.

The experimental degradation rates from Vieublé-Gonod et al. (2009) were optimized by a multiplication factor of 10, 2.4 and 4 for the SGW, MSW and CONT plot, respectively, to be able to reasonably fit observed values when no preferential flow events occurred (Fig. 4b). This was done having in mind the column study experiments performed on the same plots (Pot et al., 2011), which showed shorter half-lives ( 1.1 to 1.7 days) than the ones calculated from IPU mineralization rates (Vieublé-Gonod et al., 2009). Degradation rate was found to be a highly sensitive parameter that has a major effect on cumulative IPU loss (Filipović et al., 2014). The model could not reproduce the IPU losses measured at the end of the simulation period (2009/2010, Fig. 4b). To be able to fit the observed data points during this period, additional simulations (Fig. 6) were performed assuming temporal variation in IPU degradation rate related to IPU application history during the whole simulation period. For herbicides such as isoproturon (Hussain et al., 2013) or atrazine (Cheyns et al., 2012), it has been


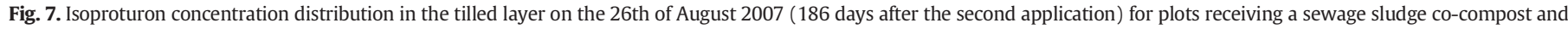
green waste (SGW) or a municipal solid waste compost (MSW) and the control plot without compost addition (CONT). 
shown that the degradation rate fluctuates with the application frequency and was related to the survival of degrader populations in the soil between two applications. Therefore, we made the assumption that the two repeated IPU applications of 2006 and 2007 induced an increased degradation rate during that particular period. On the contrary, the degradation rates were assumed to be lower for the 2009/2010 period due to the long lag phase from the former application event ( 2 years). Lowering degradation rates for the last IPU application (compared to the 1st and 2nd IPU applications) contributed to enhance leaching events for this final period. These simulations produced a better fit of the model output and produced significant improvement in model efficiency (Fig. 6). It suggests that temporal variability of pesticide degradation also should be considered in long-term modeling studies of pesticide fate in soil.

IPU concentration distribution in the tilled layer showed large spatial variations due to the presence of the different soil zones (Fig. 7). The largest concentrations were associated mostly with non-compacted soil zones in all three plots (Fig. 2), while the compacted soil zones showed smaller concentrations due to their low permeability. Interfurrows had small concentrations due to large (optimized) values of IPU degradation rate $\left(\mathrm{SGW}_{\text {deg }} \mathrm{IF}=0.673 ; \mathrm{MSW}_{\text {deg }} \mathrm{IF}=0.374\right.$; $\left.\mathrm{CONT}_{\mathrm{deg}} \mathrm{IF}=0.274 \mathrm{day}^{-1}\right)$. There were also large differences between the three plots. At the selected time (26th of August 2007) represented in Fig. 7, most of the IPU was already degraded in the SGW plot compared to the MSW plot in which high concentrations were still observed. Increasing the values of the degradation rate, i.e. multiplying it with a factor of 10 in SGW compared to a factor of 2.4 in MSW, contributed to a higher final global degradation rate for SGW compared to MSW plot. Degradation and sorption have a large influence on IPU fate. Both processes were enhanced by compost application especially in the interfurrow zones (Table 3). On the 6-year duration of the experiment, compost addition reduced IPU leaching. Besides the beneficial role of reducing IPU leaching, the two selected compost types showed multiple additional benefits: increased soil organic $\mathrm{C}$, increased crop yields, increased $\mathrm{N}$ availability and soil structure stability (Houot et al., 2005). However, the fate of the trace metals eventually contained in the composts remains an open question.

\section{Conclusions}

Two types of compost, a municipal solid waste compost (MSW) and a co-compost of sewage sludge and green wastes (SGW) have been confronted to a control treatment (CONT) in terms of cumulative field water outflow and isoproturon loss through wick lysimeters. Influence of heterogeneities in soil structure due to compost application and soil tillage on water flow and isoproturon dynamics was evaluated using HYDRUS-2D. Measured cumulative lysimeter outflow showed the largest value for the CONT plot (1388 mm) compared to the MSW (962 mm) and SGW $(979 \mathrm{~mm}$ ) plots. The model was able to describe cumulative outflow with high accuracy for all three plots after the calibration. Measured isoproturon loss had similar behavior in the two amended plots SGW $(0.663 \mu \mathrm{g})$ and MSW $(0.245 \mu \mathrm{g})$ plots, while the CONT plot had the largest isoproturon leaching $(21.31 \mu \mathrm{g})$ for the whole $2004-2010$ period. However, attributing these differences to compost applications needs caution because of the lack of replication of the experimental plots although the analyses of the basic soil properties did not reveal any difference between them. The timing of the preferential flow events could be simulated, but the corresponding leached IPU masses were not in the same order of magnitude as measured data. Additionally, temporal variation of the IPU degradation rate was assumed to explain the leaching events observed at the end of the monitoring period. Our findings demonstrate that the large spatial and temporal variations in degradation rate due to compost application and soil tillage but also to the frequency of herbicide application plays a major role in the dynamics of IPU in soil. Water and IPU fluxes were associated mostly with non-compacted soil and interfurrows while compacted clods were bypassed because of their low hydraulic conductivity. Both SGW and MSW plots showed increased sorption and degradation of IPU which prevented IPU leaching into the lysimeter plates. Application of these two compost types to an agricultural field showed benefits in terms of preventing large preferential IPU leaching. This study showed that pesticide dynamics in a heterogeneous soil profile remains a modeling challenge because of the large number of interacting processes that have to be accounted for and because of their large temporal and spatial variability.

\section{Acknowledgements}

This work was financed by the GENESIS project on groundwater systems financed by the European Commission FP7 (contract 226536), the INRA AgreenSkills support scheme and the PHC COGITO 2015 bilateral research agreement (contract 33049VJ) between France and Croatia. We acknowledge the Veolia group for financial support of the QUALIAGRO field site. We thank Christophe Labat, Guillaume Bodineau, Vincent Mercier and Jean-Noël Rampon for their support in field instrumentation and monitoring.

\section{References}

Alletto, L., Coquet, Y., Benoit, P., Heddadj, D., Barriuso, E., 2010. Tillage management effects on pesticide fate in soils. A review. Agron. Sustain. Dev. 30, 367-400. http://dx.doi. org/10.1051/agro/2009018.

Alletto, L., Pot, V., Giuliano, S., Costes, M., Perdrieux, F., Justes, E., 2015. Temporal variation in soil physical properties improves the water dynamics modeling in a conventionally-tilled soil. Geoderma 243, 18-28. http://dx.doi.org/10.1016/j. geoderma.2014.12.006.

Annabi, M., Le Bissonnais, Y., Le Villio-Poitrenaud, M., Houot, S., 2011. Improvement of soil aggregate stability by repeated applications of organic amendments to a cultivated silty loam soil. Agric. Ecosyst. Environ. 144, 382-389. http://dx.doi.org/10.1016/j. agee.2011.07.005

Beck, A.J., Harris, G.L., Howse, K.R., Johnston, A.E., Jones, K.C., 1996. Spatial and temporal variation of isoproturon residues and associated sorption/desorption parameters at the field scale. Chemosphere 33, 1283-1295. http://dx.doi.org/10.1016/00456535(96)00266-4.

Benoit, P., Barriuso, E., Vidon, P., Réal, B., 1999. Isoproturon sorption and degradation in a soil from grassed buffer strip. J. Environ. Qual. 28, 1127-1135. http://dx.doi.org/10. 2134/jeq1999.00472425002800010014x

Cabrera, A., Cox, L., Velarde, P., Koskinen, W.C., Cornejo, J., 2007. Fate of diuron and terbuthylazine in soils amended with two-phase olive oil mill waste. J. Agric. Food Chem. 55, 4828-4834. http://dx.doi.org/10.1021/jf070525b.

Cheyns, K., Martin-Laurent, F., Bru, D., Aamand, J., Vanhaecke, L., Diels, J., Merckx, R., Smolders, E., Springael, D., 2012. Long-term dynamics of the atrazine mineralization potential in surface and subsurface soil in an agricultural field as a response to atrazine applications. Chemosphere 86, 1028-1034. http://dx.doi.org/10.1016/j. chemosphere.2011.11.045.

Coquet, Y., Coutadeur, C., Labat, C., Vachier, P., Šimůnek, J., van Genuchten, M.T., RogerEstrade, J., Šimůnek, J., 2005a. Water and solute transport in a cultivated silt loam soil: 1. Field observations. Vadose Zone J. 4, 573-586. http://dx.doi.org/10.2136/vzj2004.0152.

Coquet, Y., Šimůnek, J., Coutadeur, C., van Genuchten, M.T., Pot, V., Roger-Estrade, J., 2005b. Water and solute transport in a cultivated silt loam soil: 2 . Numerical analysis. Vadose Zone J. 4, 587-601. http://dx.doi.org/10.2136/vzj2004.0153.

Coutadeur, C., Coquet, Y., Roger-Estrade, J., 2002. Variation of hydraulic conductivity in a tilled soil. Eur. J. Soil Sci. 53, 619-628.

Curtis, M.J., Claassen, V.P., 2005. Compost incorporation increases plant available water in a drastically disturbed serpentine soil. Soil Sci. 170, 939-953. http://dx.doi.org/10. 1097/01.ss.0000187352.16740.8e.

Diacono, M., Montemurro, F., 2010. Long-term effects of organic amendments on soil fertility. A review. Agron. Sustain. Dev. 30, 401-422. http://dx.doi.org/10.1051/agro/ 2009040.

Dolaptsoglou, C., Karpouzas, D.G., Menkissoglu-Spiroudi, U., Eleftherohorinos, I., Voudrias, E.A., 2007. Influence of different organic amendments on the degradation, metabolism, and adsorption of terbuthylazine. J. Environ. Qual. 36, 1793-1802. http://dx doi.org/10.2134/jeq2006.0388.

Filipe, O.M., Vidal, M.M., Scherer, H.W., Schneider, R.J., Duarte, A.C., Esteves, V.I., Santos, E.B., 2010. Effect of long term organic amendments on adsorption desorption of thiram onto a luvisol soil derived from loess. Chemosphere 80, 293-300. http://dx.doi. org/10.1016/j.chemosphere.2010.04.003.

Filipović, V., Coquet, Y., Pot, V., Houot, S., Benoit, P., 2014. Modeling the effect of soil structure on water flow and isoproturon dynamics in an agricultural field receiving repeated urban waste compost application. Sci. Total Environ. 499, 546-559. http:// dx.doi.org/10.1016/j.scitotenv.2014.06.010.

Houot, S., Bodineau, G., Rampon, J.N., Annabi, M., Francou, C., Poittrenaud, M., 2005. Agricultural use of different residual waste composts - current situation and experiences in France. The Future of Residual Waste Management in Europe (http://www. compost.it/biblio/2005_luxembourg/vortraege/houot-doc.pdf). 
Houot, S., Cambier, P., Benoit, P., Bodineau, G., Deschamps, M., Jaulin, A., Lhoutellier, C., Barriuso, E., 2009. Effet d'apports de composts sur la disponibilité de micropolluants métalliques et organiques dans un sol cultivé. Etude Gestion des Sols 16 (3-4), 255-274.

Houot, S., Clergeot, D., Michelin, J., Francou, C., Bourgeois, S., Caria, G., Ciesielski, H., 2002. Agronomic value and environmental impacts of urban composts used in agriculture. In: Insam, H., Klammer, S. (Eds.), Microbiology of Composting. Springer-Verlag, Berlin Heidelberg, pp. 457-472.

Hussain, S., Devers-Lamrani, M., Spor, A., Rouard, N., Porcherot, M., Beguet, J., MartinLaurent, F., 2013. Mapping field spatial distribution patterns of isoproturonmineralizing activity over a three-year winter wheat/rape seed/barley rotation. Chemosphere 90, 2499-2511. http://dx.doi.org/10.1016/j.chemosphere.2012.10.080.

IUSS Working Group WRB, 2014. World reference base for soil resources 2014. International Soil Classification System for Naming Soils and Creating Legends for Soil MapsWorld Soil Resources Reports No. 106. FAO, Rome.

Klute, A., Dirksen, C., 1986. Hydraulic conductivity and diffusivity: laboratory methods. Methods of Soil Analysis. Part 1. Physical and Mineralogical Methods Agronomy Monograph no. 9. ASA-SSSA, Madison, USA

Kodešová, R., Kočárek, M., Hajková, T., Hýbler, M., Drábek, O., Kodeš, V., 2012. Chlorotoluron mobility in compost amended soil. Soil Tillage Res. 118, 88-96. http://dx.doi.org/10.1016/j.still.2011.10.014.

Manichon, H., 1982. Influence of cropping systems on the cultivation profile: development of a diagnostic method based on morphological observation [in French] (PhD dissertation) INAPG, Paris.

Mualem, Y., 1976. A new model for predicting the hydraulic conductivity of unsaturated porous media. Water Resour. Res. 12, 513-522. http://dx.doi.org/10.1029/ WR012i003p00513.

Nash, J.E., Sutcliffe, J.V., 1970. River flow forecasting through conceptual models. Part I. A discussion of principles. J. Hydrol. 10, 282-290.

Pot, V., Benoit, P., Etievant, V., Bernet, N., Labat, C., Coquet, Y., Houot, S., 2011. Effects of tillage practice and repeated urban compost application on bromide and isoproturon transport in a loamy Albeluvisol. Eur. J. Soil Sci. 62, 797-810. http://dx.doi.org/10. 1111/j.1365-2389.2011.01402.x.

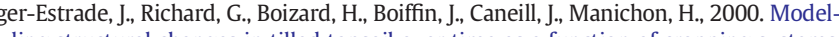
ling structural changes in tilled topsoil over time as a function of cropping systems. Eur. J. Soil Sci. 51, 455-474.

Schneider, S., Coquet, Y., Vachier, P., Labat, C., Roger-Estrade, J., Benoit, P., Pot, V., Houot, S., 2009. Effect of urban waste compost application on soil near-saturated hydraulic conductivity. J. Environ. Qual. 38, 772-781. http://dx.doi.org/10.2134/jeq2008.0098.

Šimůnek, J., van Genuchten, M.T., Šejna, M., 2008. Development and applications of the HYDRUS and STANMOD software packages and related codes. Vadose Zone J. 7, 587-600. http://dx.doi.org/10.2136/vzj2007.0077.

SOeS, 2012. French national service for the environment. Groundwater Contamination by Pesticides; [in French].

Strudley, M.W., Green, T.R., Ascough, J.C., 2008. Tillage effects on soil hydraulic properties in space and time: state of the science. Soil Till. Res. 99, 4-48. http://dx.doi.org/10. 1016/j.still.2008.01.007.

van Genuchten, M.T., 1980. A closed-form equation for predicting the hydraulic conductivity of unsaturated soils. Soil Sci. Soc. Am. J. 44, 892-898. http://dx.doi.org/10. 2136/sssaj1980.03615995004400050002x.

van Genuchten, M.T., Leij, F.J., Yates, S.R., 1991. The RETC code for quantifying the hydraulic functions of unsaturated soils, version 1.0. EPA Report 600/2-91/065. U.S. Salinity Laboratory, USDA, ARS, Riverside, California.

Vieublé-Gonod, L., Benoit, P., Cohen, N., Houot, S., 2009. Spatial and temporal heterogeneity of soil microorganisms and isoproturon degrading activity in a tilled soil amended with urban waste composts. Soil Biol. Biochem. 41, 2558-2567. http://dx.doi.org/10. 1016/j.soilbio.2009.09.017.

Wong, J.W.C., Ma, K.K., Fang, K.M., Cheung, C., 1999. Utilization of a manure compost for organic farming in Hong Kong. Bioresour. Technol. 67, 43-46. http://dx.doi.org/10. 1016/S0960-8524(99)00066-8.

Yang, H., Wu, X., Zhou, L.X., Yang, Z.M., 2005. Effect of dissolved organic matter on chlorotoluron sorption and desorption. Pedosphere 15, 432-439. 